\title{
In Search for Titanocene Complexes with Improved Cytotoxic Activity: Synthesis, X-Ray Structure, and Spectroscopic Study of Bis $\left(\eta^{5}\right.$-cyclopentadienyl)difluorotitanium(IV)
}

\author{
Elias Koleros, ${ }^{1}$ Theocharis C. Stamatatos, ${ }^{1}$ Vassilis Psycharis, ${ }^{2}$ Catherine P. Raptopoulou, ${ }^{2}$ \\ Spyros P. Perlepes, ${ }^{1}$ and Nikolaos Klouras ${ }^{1}$ \\ ${ }^{1}$ Department of Chemistry, University of Patras, 26504 Patras, Greece \\ ${ }^{2}$ National Center of Scientific Research, "Demokritos" (NCSR), Institute of Materials Science, Aghia Paraskevi, 15310 Attikis, Greece \\ Correspondence should be addressed to Nikolaos Klouras, n.klouras@chemistry.upatras.gr
}

Received 27 March 2010; Accepted 3 May 2010

Academic Editor: Evy Manessi-Zoupa

Copyright ( $) 2010$ Elias Koleros et al. This is an open access article distributed under the Creative Commons Attribution License, which permits unrestricted use, distribution, and reproduction in any medium, provided the original work is properly cited.

The $1: 2$ reaction of $\left[\mathrm{Ti}\left(\eta^{5}-\mathrm{C}_{5} \mathrm{H}_{5}\right)_{2} \mathrm{Cl}_{2}\right]$ and $\mathrm{AgF}$ in $\mathrm{CHCl}_{3} / \mathrm{H}_{2} \mathrm{O}$ yielded the fluoro analog $\left[\mathrm{Ti}\left(\eta^{5}-\mathrm{C}_{5} \mathrm{H}_{5}\right)_{2} \mathrm{~F}_{2}\right](\mathbf{1})$ in almost quantitative yield $\left(\mathrm{C}_{5} \mathrm{H}_{5}\right.$ is the cyclopentadienyl group). The coordination about the $\mathrm{Ti}^{\mathrm{IV}}$ atom formed by two fluoro ligands and the centroids of the cyclopentadienyl rings is distorted tetrahedral. The compound crystallizes in the orthorhombic space group C2cm. The lattice constants are $a=5.9055(4), b=10.3021(5), c=14.2619(9) \AA$, and $\alpha=\beta=\gamma=90^{\circ}$. The complex has been characterized by elemental analyses and spectroscopic (IR, ${ }^{1} \mathrm{H}$ NMR) data. A structural comparison of the four members of the $\left[\mathrm{Ti}\left(\eta^{5}-\mathrm{C}_{5} \mathrm{H}_{5}\right)_{2} \mathrm{X}_{2}\right]$ family of complexes $(\mathrm{X}=\mathrm{F}, \mathrm{Cl}, \mathrm{Br}, \mathrm{I})$ is attempted.

\section{Introduction}

One of the first metal complexes discovered to exhibit biological activity has been cisplatin, $\left[\mathrm{Pt}\left(\mathrm{NH}_{3}\right)_{2} \mathrm{Cl}_{2}\right][1]$. It is considered as one of the most efficient drugs for the treatment of certain types of cancer; however, drug toxicity and resistance limit its utilization for a broader range of diseases. In recent years, there has been a growing interest in the development of nonplatinum-based anticancer therapeutics. The main goal is to increase the variety of potential drugs, which may lead to higher activities enabling the administration of lower doses, attack of different types of tumour cells, solution of drug resistance problems, better selectivity and to lower toxicity. Non-platinum complexes may introduce numerous options for coordination numbers and geometries, oxidation states, affinity for certain types of biological ligands, and so forth, and may thus operate by different mechanisms. One class of such complexes are metallocene dihalides.

Metallocene dihalides, $\left[\mathrm{M}\left(\eta^{5}-\mathrm{C}_{5} \mathrm{H}_{5}\right)_{2} \mathrm{X}_{2}\right](\mathrm{M}=\mathrm{Ti}, \mathrm{V}, \mathrm{Nb}$, Mo, Re; $\mathrm{X}=$ halide ligand; $\mathrm{C}_{5} \mathrm{H}_{5}=\mathrm{Cp}$, the cyclopentadienyl group), are a relatively new class of small hydrophobic organometallic anticancer agents that exhibit antitumour activities against cancer cell lines, such as leukaemias P388 and L1210, colon 38 and Lewis lung carcinomas, B16 melanoma, solid and fluid Ehrlich ascites tumours and also against human colon, renal and lung carcinomas transplanted into athymic mice [2-5]. Titanocene dichloride, $\left[\mathrm{Ti}\left(\eta^{5}-\mathrm{C}_{5} \mathrm{H}_{5}\right)_{2} \mathrm{Cl}_{2}\right]$, is the most widely studied metallocene compound as a cytotoxic anticancer agent, which means that it can selectively kill cancer cells, and was used in phase I and II clinical trials [6-13]. However, the efficacy of $\left[\mathrm{Ti}\left(\eta^{5}-\mathrm{C}_{5} \mathrm{H}_{5}\right)_{2} \mathrm{Cl}_{2}\right]$ in phase II clinical trials in patients with metastatic renal cell carcinoma [12] or metastatic breast cancer [13] was too low to be pursued. As titanium is present in many biomaterials, such as in food in the form of a whitening pigment, it is not unreasonable to conceive that it may be incorporated into drugs and into living systems, with particularly low toxicity [14].

In 2008, a novel class of substituted titanocene dichlorides, the so-called "benzyl-substituted titanocenes", with improved cytotoxic activity were developed and tested for their potential application as anticancer drugs [15]. The cytotoxic activity can also be influenced by substitution 
of the two chloride ligands. More recently, Huhn and coworkers reported the synthesis and cytotoxicity of selected benzyl-substituted fluorotitanocene derivatives that showed a cytotoxic activity $3-5$ fold higher than that of the respective dichlorides [16]. In the same paper, the X-ray structure analysis of two of the titanocene difluoride derivatives was also described. The prototype of the latter compounds is titanocene difluoride, $\left[\mathrm{Ti}\left(\eta^{5}-\mathrm{C}_{5} \mathrm{H}_{5}\right)_{2} \mathrm{~F}_{2}\right]$, which itself (i) exhibits strong antitumor, anti-inflammatory and antiarthritic activity as well as immunosuppressant effects [17, 18], (ii) reduces significantly the rates of crystal growth of hydroxyapatite (the model compound for the inorganic component of bones and teeth, observed in pathological calcifications of the articular cartilage) [19], and (iii) is an effective catalyst for the reduction of lactones and imines, reductive-deoxygenative coupling of amides, hydrogenation of olefins, and defluorination of saturated perfluorocarbons [20].

Surprisingly, the crystal structure of bis $\left(\eta^{5}\right.$-cyclopentadienyl)difluorotitanium(IV) is not known. In the present work, we describe the first X-ray diffraction study of $\left[\mathrm{Ti}\left(\eta^{5}\right.\right.$ $\left.\mathrm{C}_{5} \mathrm{H}_{5}\right)_{2} \mathrm{~F}_{2}$ ], providing structural data which will probably be important in structure-activity investigations of new titanocene difluorides, a promising class in terms of medical applications.

\section{Experiments}

Reagents and solvents were purchased from commercial sources, and were purified (where necessary) and dried before use by standard procedures. The starting titanocene dichloride, $\left[\mathrm{Ti}\left(\eta^{5}-\mathrm{C}_{5} \mathrm{H}_{5}\right)_{2} \mathrm{Cl}_{2}\right]$, was synthesized under an argon atmosphere using dried THF by the method of Wilkinson and Birmingham [21] and recrystallized from boiling toluene. All manipulations were performed under aerobic conditions. Microanalyses $(\mathrm{C}, \mathrm{H})$ were performed by the University of Patras (Greece) Microanalytical Laboratory using an EA 1108 Carlo Erba analyzer. IR spectra (4000$450 \mathrm{~cm}^{-1}$ ) were recorded on a Perkin-Elmer 16 PC FTspectrometer with samples prepared as $\mathrm{KBr}$ pellets. The ${ }^{1} \mathrm{H}$ NMR spectrum of the complex in $\mathrm{CDCl}_{3}$ was recorded with a Bruker Avance $400 \mathrm{MHz}$ spectrometer; chemical shifts are reported relative to tetramethylsilane. Conductivity measurements were carried out at $25^{\circ} \mathrm{C}$ using an EhrhardtMetzger, type L21, conductivity bridge.

$\left[\mathrm{Ti}\left(\eta^{5}-\mathrm{C}_{5} \mathrm{H}_{5}\right)_{2} \mathrm{~F}_{2}\right](\mathbf{1})$ was synthesized in a plastic bottle from a solution of the dichloride, $\left[\mathrm{Ti}\left(\eta^{5}-\mathrm{C}_{5} \mathrm{H}_{5}\right)_{2} \mathrm{Cl}_{2}\right]$ ( $5 \mathrm{mmol}$ ), in $\mathrm{CHCl}_{3}$ by adding a freshly prepared aqueous solution of $\mathrm{AgF}$ ( $10 \mathrm{mmol}$ ) according to the procedure described in [22]. The reaction mixture was shaken vigorously for 20 minutes at room temperature. During this time, the colour of the organic phase changed from red to orange and finally to yellow. The yellow $\mathrm{CHCl}_{3}$ phase was separated from the aqueous phase, containing the white precipitate of $\mathrm{AgCl}$, through a separatory funnel and filtered. Condensation of the yellow filtrate under reduced pressure gave a fluffy lemon-yellow solid that was dried in vacuo over silica gel and recrystallized from toluene. Yield 90\% and m.p. $235^{\circ} \mathrm{C}$ (dec.) Lemon-yellow, needle-like crystals of $\mathbf{1}$ suitable
TABLE 1: Crystallographic data and structure refinement for complex 1 .

\begin{tabular}{|c|c|}
\hline Empirical formula & $\mathrm{C}_{40} \mathrm{H}_{40} \mathrm{Ti}_{4} \mathrm{~F}_{8}$ \\
\hline Formula weight $\left(\mathrm{g} \mathrm{mol}^{-1}\right)$ & 864.32 \\
\hline Colour and habit & Yellow prisms \\
\hline Crystal size (mm) & $0.75 \times 0.10 \times 0.10$ \\
\hline Crystal system & Orthorhombic \\
\hline Space group & $\mathrm{C} 2 \mathrm{~cm}$ \\
\hline \multicolumn{2}{|l|}{ Unit cell dimensions } \\
\hline$a, \AA$ & $5.9055(4)$ \\
\hline$b, \AA$ & $10.3021(5)$ \\
\hline$c, \AA$ & $14.2616(9)$ \\
\hline$\alpha,{ }^{\circ}$ & 90 \\
\hline$\beta,{ }^{\circ}$ & 90 \\
\hline$\gamma,^{\circ}$ & 90 \\
\hline$V, \AA^{3}$ & $867.66(9)$ \\
\hline$Z$ & 1 \\
\hline$\rho, \mathrm{Mg} \mathrm{m}^{-3}$ & 1.654 \\
\hline$T, \mathrm{~K}$ & $160(2)$ \\
\hline Radiation $(\AA)$ & $\mathrm{Cu} \mathrm{K} \alpha(\lambda=1.54178)$ \\
\hline$\mu, \mathrm{mm}^{-1}$ & 8.207 \\
\hline$F(000)$ & 440 \\
\hline$\theta$ range $\left(^{\circ}\right)$ & $8.61-59.99$ \\
\hline \multirow[t]{3}{*}{ Index ranges, ${ }^{\circ}$} & $-6 \leq h \leq 6$ \\
\hline & $-11 \leq k \leq 11$ \\
\hline & $-14 \leq l \leq 12$ \\
\hline Measured reflections & 2894 \\
\hline Unique reflections & $613\left(R_{\mathrm{int}}=0.0947\right)$ \\
\hline Reflections used $[I>2 \sigma(I)]$ & 535 \\
\hline Parameters refined & 60 \\
\hline GoF $\left(\right.$ on $\left.F^{2}\right)$ & 1.100 \\
\hline$R 1^{\mathrm{a}}[I>2 \sigma(I)]$ & 0.0668 \\
\hline$w R 2^{\mathrm{b}}[I>2 \sigma(I)]$ & 0.1469 \\
\hline$(\Delta \rho)_{\max } /(\Delta \rho)_{\min }, \mathrm{e} \AA^{-3}$ & $1.183 /-0.680$ \\
\hline
\end{tabular}

for X-ray analysis were obtained by vapour diffusion of petroleum ether into a $\mathrm{CHCl}_{3}$ solution of the product placed in an $\mathrm{H}$-shaped tube. Anal. Calc. for $\mathrm{C}_{10} \mathrm{H}_{10} \mathrm{~F}_{2} \mathrm{Ti}$ (216.08): C, 55.59; H, 4.66. Found: C, 55.28; H, 4.62. Selected IR data $\left(\mathrm{KBr}, \mathrm{cm}^{-1}\right)$ : 3108 (s), 1442 (s), 1362 (w), 1016 (s), 874 (m), 822 (vs), 610 (w), 564 (s), 539 (m). ${ }^{1} \mathrm{H}$ NMR (400 MHz, $\left.\mathrm{CDCl}_{3}\right): \delta 6.53(\mathrm{t})$.

2.1. X-Ray Crystallographic Studies. A yellow prismatic crystal of 1 was taken directly from the mother liquid and immediately cooled to $-113^{\circ} \mathrm{C}$. Diffraction measurements were made on a Rigaku R-AXIS SPIDER Image Plate diffractometer using graphite monochromated $\mathrm{Cu} \mathrm{K} \alpha$ radiation. Data collection ( $\omega$-scans) and processing (cell refinement, data reduction and empirical absorption correction) were performed using the CRYSTALCLEAR program package [23]. Important crystal data and parameters for data collection and refinement are listed in Table 1. The structure was 
TABLe 2: Selected bond lengths $(\AA)$ and angles $\left(^{\circ}\right)$ for complex $1 .^{\mathrm{a}}$

\begin{tabular}{lccc}
\hline Ti-F(1) & $1.853(4)$ & Ti-C $(3)$ & $2.363(9)$ \\
Ti-F(2) & $1.859(4)$ & Ti-C $(4)$ & $2.365(10)$ \\
Ti-C(1) & $2.375(11)$ & Ti-C $(5)$ & $2.396(11)$ \\
$\operatorname{Ti}-\mathrm{C}(2)$ & $2.400(11)$ & Ti-Cp & 2.066 \\
$\mathrm{C}(1)-\mathrm{C}(2)$ & $1.358(15)$ & $\mathrm{C}(4)-\mathrm{C}(5)$ & $1.386(14)$ \\
$\mathrm{C}(2)-\mathrm{C}(3)$ & $1.396(14)$ & $\mathrm{C}(5)-\mathrm{C}(1)$ & $1.390(15)$ \\
$\mathrm{C}(3)-\mathrm{C}(4)$ & $1.411(16)$ & $\mathrm{F}(1)-\mathrm{Ti}-\mathrm{Cp}$ & 1.388 \\
\hline $\mathrm{F}(1)-\mathrm{Ti}-\mathrm{F}(2)$ & $96.0(2)$ & $\mathrm{F}(2)-\mathrm{Ti}-\mathrm{Cp}$ & 107.30 \\
$\mathrm{Cp}-\mathrm{Ti}-\mathrm{Cp}{ }^{\prime}$ & 128.53 & $\mathrm{C}(4)-\mathrm{C}(5)-\mathrm{C}(1)$ & 106.46 \\
$\mathrm{C}(1)-\mathrm{C}(2)-\mathrm{C}(3)$ & $108.6(10)$ & $\mathrm{C}(5)-\mathrm{C}(1)-\mathrm{C}(2)$ & $107.5(10)$ \\
$\mathrm{C}(2)-\mathrm{C}(3)-\mathrm{C}(4)$ & $106.8(7)$ & Aver. C-C-C & $109.2(13)$ \\
$\mathrm{C}(3)-\mathrm{C}(4)-\mathrm{C}(5)$ & $107.8(8)$ & & 108.0 \\
\hline
\end{tabular}

a Primed atoms are related to the unprimed ones by the symmetry operation $x, y, 1 / 2-z$.

solved by direct methods using SHELXS-97 [24] and refined by full-matrix least-squares techniques on $F^{2}$ with SHELXL97 [25]. Hydrogen atoms of the cyclopentadienyl (Cp) group were introduced at calculated positions as riding on bonded atoms. All non-H atoms were refined anisotropically. In the structure of 1 , the carbon atoms of one of the two $\mathrm{Cp}$ rings are disordered over symmetry-related positions. CCDC 771089 contains the supplementary crystallographic data for this paper. These data can be obtained free of charge at http://www.ccdc.cam.ac.uk/conts/retrieving.hmtl (or from the Cambridge Crystallographic Data Centre, 12 Union Road, Cambridge CB2 1EZ, UK; Fax: (internat.) ++ 44-1223/336-033; E-mail: deposit@ccdc.cam.ac.uk).

\section{Results and Discussion}

3.1. Synthetic Comments. The title compound was first prepared by Wilkinson and Birmingham in 1954 by dissolving the bromo analog, $\left[\mathrm{Ti}\left(\eta^{5}-\mathrm{C}_{5} \mathrm{H}_{5}\right)_{2} \mathrm{Br}_{2}\right]$, in hot 12 $N$ hydrofluoric acid and heating on a steam-bath until the solution was pale yellow in colour. On cooling, yellow crystals were received which were recrystallized from $3 \mathrm{~N}$ hydrofluoric acid solution [21]. Among the other published in the literature methods, we selected that described by Pink in his Thesis. The method uses AgF prepared in situ, which gives the best yields in the shortest time [29]. The preparation of $\mathbf{1}$ involves the reactions represented by the stoichiometric equations (1)-(3):

$$
\begin{aligned}
& 2 \mathrm{AgNO}_{3}+2 \mathrm{NaOH} \longrightarrow \mathrm{Ag}_{2} \mathrm{O}+2 \mathrm{NaNO}_{3}+\mathrm{H}_{2} \mathrm{O} \\
& \mathrm{Ag}_{2} \mathrm{O}+2 \mathrm{HF} \longrightarrow 2 \mathrm{AgF}+\mathrm{H}_{2} \mathrm{O} \\
& {\left[\mathrm{Ti}\left(\eta^{5}-\mathrm{C}_{5} \mathrm{H}_{5}\right)_{2} \mathrm{Cl}_{2}\right]+2 \mathrm{AgF} } \\
& \stackrel{\mathrm{CHCl} / \mathrm{H}_{2} \mathrm{O}}{\longrightarrow}\left[\mathrm{Ti}\left(\eta^{5}-\mathrm{C}_{5} \mathrm{H}_{5}\right)_{2} \mathrm{~F}_{2}\right]+2 \mathrm{AgCl}
\end{aligned}
$$

The two first steps ((1) and (2)) are necessary because AgF decomposes upon staying. Experiments with commercial $\mathrm{AgF}$ always lead to poor yields. Another method for a highyield synthesis of $\mathbf{1}$ was developed by Ruzicka and coworkers

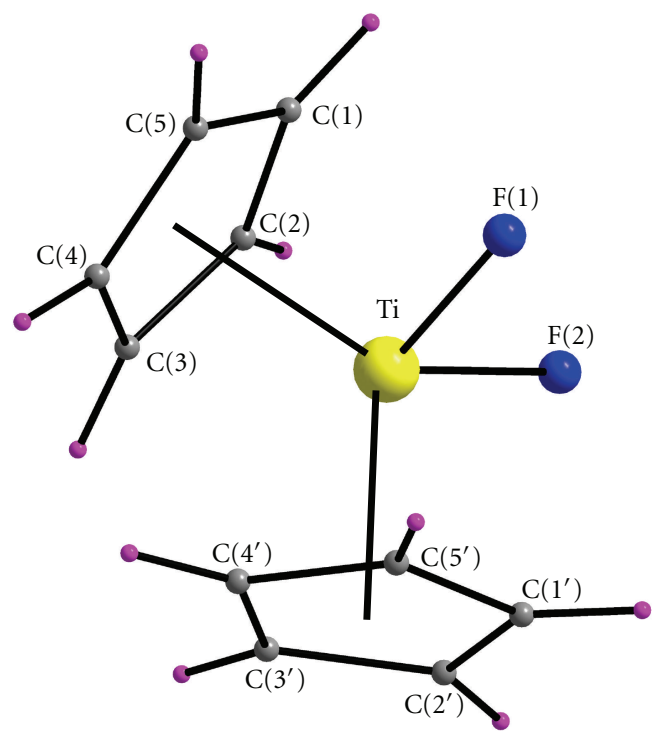

FIGURE 1: Labeled PovRay representation of complex 1 with the atom numbering scheme. Primes are used for symmetry-related atoms. Colour scheme: $\mathrm{Ti}^{\mathrm{IV}}$, yellow; F, blue; C, gray; $\mathrm{H}$, purple.

[30] and involves the $1: 2$ reaction of $\left[\mathrm{Tii}\left(\eta^{5}-\mathrm{C}_{5} \mathrm{H}_{5}\right)_{2} \mathrm{Cl}_{2}\right]$ and the good fluorinating agent $\left\{2-\left[\left(\mathrm{CH}_{3}\right)_{2} \mathrm{NCH}_{2}\right] \mathrm{C}_{6} \mathrm{H}_{4}\right\}(\mathrm{n}$ $\mathrm{Bu})_{2} \mathrm{SnF}$ in $\mathrm{CH}_{2} \mathrm{Cl}_{2}$.

Complex $\mathbf{1}$ is, like $\left[\mathrm{Ti}\left(\eta^{5}-\mathrm{C}_{5} \mathrm{H}_{5}\right)_{2} \mathrm{Cl}_{2}\right]$, a very stable compound. It dissolves easily in common organic solvents such as chloroform, methanol, benzene, toluene and is much more soluble in water than are the other congener halides, even at room temperature, without decomposition. A decent water solubility is essential for a satisfactory cytotoxic activity of titanium(IV) complexes. Its molar conductivity $\left(\mathrm{H}_{2} \mathrm{O}\right.$, $10^{-3} \mathrm{M}, 25^{\circ} \mathrm{C}$ ) is less than $5 \mathrm{~S} \mathrm{~cm}^{2} \mathrm{~mol}^{-1}$. This means that, in contrast to the other corresponding titanocene dihalides, the fluoride ligands in $\mathbf{1}$ are hydrolytically stable. In this case, the water solubility and negligible molar conductivity could be attributed to the formation of hydrogen bonds between the electronegative $\mathrm{F}^{-}$ligands of $\mathbf{1}$ and the $\mathrm{H}_{2} \mathrm{O}$ molecules rather than to a dissociation of the complex to species 
TABLE 3: Comparison of some important molecular parameters (average values) for the four prototype titanocene dihalogenides, [Ti $\left(\eta^{5}\right.$ $\left.\left.\mathrm{C}_{5} \mathrm{H}_{5}\right)_{2} \mathrm{X}_{2}\right]$.

\begin{tabular}{|c|c|c|c|c|c|}
\hline Compound & $\mathrm{Ti}-\mathrm{Cp}^{\mathrm{a}}(\AA)$ & $\operatorname{Ti}-\mathrm{X}(\AA)$ & $\mathrm{Cp}-\mathrm{Ti}-\mathrm{Cp}\left({ }^{\circ}\right)$ & $\mathrm{X}-\mathrm{Ti}-\mathrm{X}\left({ }^{\circ}\right)$ & Ref. \\
\hline$\left[\mathrm{Ti}\left(\eta^{5}-\mathrm{C}_{5} \mathrm{H}_{5}\right)_{2} \mathrm{~F}_{2}\right]$ & 2.066 & 1.856 & 128.5 & 96.0 & present work \\
\hline$\left[\mathrm{Ti}\left(\eta^{5}-\mathrm{C}_{5} \mathrm{H}_{5}\right)_{2} \mathrm{Cl}_{2}\right]$ & 2.059 & 2.364 & 131.0 & 94.5 & {$[26]$} \\
\hline$\left[\mathrm{Ti}\left(\eta^{5}-\mathrm{C}_{5} \mathrm{H}_{5}\right)_{2} \mathrm{Br}_{2}\right]$ & 2.058 & 2.493 & 131.6 & 94.9 & [27] \\
\hline$\left[\mathrm{Ti}\left(\eta^{5}-\mathrm{C}_{5} \mathrm{H}_{5}\right)_{2} \mathrm{I}_{2}\right]$ & 2.045 & 2.769 & 132.3 & 92.8 & {$[28]$} \\
\hline
\end{tabular}

${ }^{\mathrm{a}} \mathrm{Cp}=\eta^{5}$-cyclopentadienyl ring.

TABLE 4: Comparison of unit cell parameters for the four prototype titanocene dihalogenides, $\left[\mathrm{Ti}\left(\eta^{5}-\mathrm{C}_{5} \mathrm{H}_{5}\right)_{2} \mathrm{X}_{2}\right]$.

\begin{tabular}{|c|c|c|c|c|c|c|c|c|}
\hline Compound & $a(\AA)$ & $b(\AA)$ & $c(\AA)$ & $\alpha\left(^{\circ}\right)$ & $\beta\left(^{\circ}\right)$ & $\gamma\left({ }^{\circ}\right)$ & Crystal system & Ref. \\
\hline$\left[\mathrm{Ti}\left(\eta^{5}-\mathrm{C}_{5} \mathrm{H}_{5}\right)_{2} \mathrm{~F}_{2}\right]$ & $5.9055(4)$ & $10.3021(5)$ & $14.2616(9)$ & 90 & 90 & 90 & Orthorhombic & present work \\
\hline$\left[\mathrm{Ti}\left(\eta^{5}-\mathrm{C}_{5} \mathrm{H}_{5}\right)_{2} \mathrm{Cl}_{2}\right]$ & $7.882(5)$ & $19.478(10)$ & $12.156(9)$ & $90.46(2)$ & $102.58(2)$ & $143.49(2)$ & Triclinic & {$[26]$} \\
\hline$\left[\mathrm{Ti}\left(\eta^{5}-\mathrm{C}_{5} \mathrm{H}_{5}\right)_{2} \mathrm{Br}_{2}\right]$ & $7.872(5)$ & $11.807(5)$ & $12.310(3)$ & $107.62(3)$ & $100.83(4)$ & $90.69(4)$ & Triclinic & [27] \\
\hline$\left[\mathrm{Ti}\left(\eta^{5}-\mathrm{C}_{5} \mathrm{H}_{5}\right)_{2} \mathrm{I}_{2}\right]$ & $13.426(4)$ & $7.173(2)$ & $13.096(4)$ & 90 & $116.686(5)$ & 90 & Monoclinic & {$[28]$} \\
\hline
\end{tabular}

${ }^{\mathrm{a}} \mathrm{Cp}=\eta^{5}$-cyclopentadienyl ring.
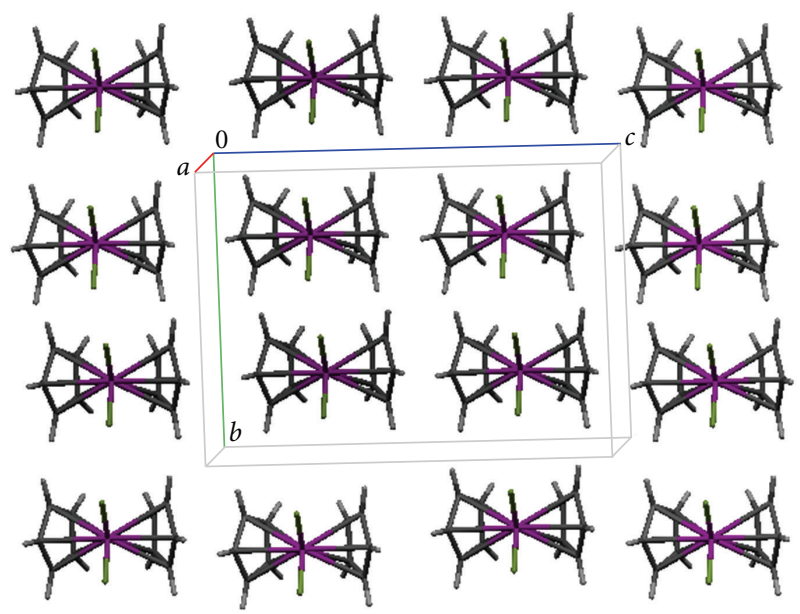

FIGURE 2: Drawing of the crystalline packing of complex 1.

like $\left[\mathrm{Ti}\left(\eta^{5}-\mathrm{C}_{5} \mathrm{H}_{5}\right)_{2}\left(\mathrm{H}_{2} \mathrm{O}\right)_{2}\right]^{2+}$ and $\mathrm{F}^{-}$. The oxophilicity of $\mathrm{Ti}^{\mathrm{IV}}$ makes complexes of this metal ion with organic and inorganic ligands highly susceptible to hydrolysis. Complexes of hydrolytic instability are not biologically active, probably due to rapid formation of inactive aggregates [14].

3.2. Spectroscopic Characterization. The IR spectra of $\pi$ bonded cyclopentadienyl metal complexes have been studied [31-33]. In the IR spectrum of 1 the bands at 3108, 1442, $1016,874 / 822$ and $610 \mathrm{~cm}^{-1}$ can be assigned [31-33] to the $v(\mathrm{CH}), v(\mathrm{CC}), \delta(\mathrm{CH}), \pi(\mathrm{CH})$ and $\delta(\mathrm{CCC})$ vibrational modes, respectively. The bands at 564 and $539 \mathrm{~cm}^{-1}$ are assigned [32] to the $v_{1}\left(A_{1}\right)$ and $v_{6}\left(B_{1}\right)$ (under $C_{2 V}$ point group symmetry) stretching modes of the terminal $\mathrm{Ti}^{\mathrm{IV}}-\mathrm{F}$ bonds.

The ${ }^{1} \mathrm{H}$ NMR spectrum $\left(\mathrm{CDCl}_{3}\right)$ of 1 shows a triplet peak at $\delta=6.53 \mathrm{ppm}$ corresponding to the equivalent protons of the $\eta^{5}-\mathrm{C}_{5} \mathrm{H}_{5}$ protons $[31,34]$. The triplet character of the signal is due to the small ${ }^{3} J$ coupling $(1.7 \mathrm{~Hz})$ between the cyclopentadienyl protons and the fluoro nuclei in the molecule [34].

3.3. Description of Structure. The molecular structure and a crystal packing diagram of 1 are shown in Figures 1 and 2, respectively. Bond lengths and angles are listed in Table 2.

The structure of $\mathbf{1}$ consists of isolated $\left[\mathrm{Ti}^{\mathrm{iV}}\left(\eta^{5}-\right.\right.$ $\left.\left.\mathrm{C}_{5} \mathrm{H}_{5}\right)_{2} \mathrm{~F}_{2}\right]$ molecules. The molecule has the familiar, distorted tetrahedral shape found in the chloro [26], bromo [27] and iodo [28] members of the $\left[\mathrm{Ti}^{\mathrm{IV}}\left(\eta^{5}-\mathrm{C}_{5} \mathrm{H}_{5}\right)_{2} \mathrm{X}_{2}\right]$ family of complexes. The distorted tetrahedral structure arises if we consider the $\mathrm{Cp}$ ring centroids as each occupying one coordination site around the metal ion. The cyclopentadienyl centroid-titanium-cyclopentadienyl centroid angle is $128.53^{\circ}$, and the fluorine-titanium-fluorine angle is $96.0^{\circ}$. The $\mathrm{TiF}_{2}$ group defines a symmetry plane and there is thus one crystallographically independent $\mathrm{Cp}$ ligand. The plane defined by the $\mathrm{Ti}^{\mathrm{IV}}$ atom and the centroids of the $\mathrm{Cp}$ rings bisects the F-Ti-F bond angle. Thus, the molecule has a 2fold symmetry about the line of intersection of this plane and the plane of the F-Ti-F bond angle; its point group symmetry is $C_{2 \mathrm{v}}$. The $\mathrm{Cp}$ ring is planar to $\pm 0.019 \AA$. The least-squares planes of the two symmetry related $\mathrm{Cp}$ rings in the bent $(\mathrm{Cp})_{2}$ Ti fragment of $\mathbf{1}$ form a dihedral angle of $53.49^{\circ}$. The two $\mathrm{Cp}$ rings exhibit a staggered conformation. The angle between the normals to ring planes is $53.83^{\circ}$.

The five $\mathrm{Ti}-\mathrm{C}$ bond lengths range from 2.363(9) to 2.400(11) $\AA$. This narrow range establishes a distinct pentahapto coordination mode for each $\mathrm{Cp}$ ligand in $\mathbf{1}$. The mean Ti-C bond distance (2.380 $\AA$ ) is in agreement with the corresponding values of other bis(cyclopentadienyl)titanium(IV) complexes, for example, the value of $2.370 \AA$ in $\left[\operatorname{Ti}\left(\eta^{5}-\right.\right.$ $\left.\mathrm{C}_{5} \mathrm{H}_{5}\right)_{2} \mathrm{Cl}_{2}$ ] [26]. The $\mathrm{Ti}^{\mathrm{iV}}$-F bond distances [1.853(4), $1.859(4) \AA]$ are similar to those found in other 4-coordinate titanium(IV) complexes containing terminal Ti-F bonds [ 16 , $35,36]$. The $\mathrm{C}-\mathrm{C}$ bond lengths in the $\mathrm{Cp}$ ring of 1 with an average value of $1.388 \AA$ are within the usual range 
reported for organometallic complexes containing $\mathrm{Cp}^{-}$rings [27].

Since the single-crystal, $\mathrm{X}$-ray structures of all the four members of the $\left[\mathrm{Ti}\left(\eta^{5}-\mathrm{C}_{5} \mathrm{H}_{5}\right)_{2} \mathrm{X}_{2}\right](\mathrm{X}=\mathrm{F}, \mathrm{Cl}, \mathrm{Br}, \mathrm{I})$ family are now known, we feel it is interesting to compare some of their important structural and crystallographic parameters. The comparisons are presented in Tables 3 and 4, respectively. The average distance from the $\mathrm{Ti}^{\mathrm{IV}}$ atom to the ring centroid and the angle between the vectors from the metal center to each of the ring centroids vary by less than $0.025 \AA$ and $4^{\circ}$, respectively, across the four complexes. The F-Ti-F angle $\left(96.0^{\circ}\right)$ is slightly wider than the corresponding $\mathrm{X}-\mathrm{Ti}-\mathrm{X}(\mathrm{X}$ $=\mathrm{Cl}, \mathrm{Br}, \mathrm{I})$ angles $\left(92.8-94.5^{\circ}\right)$ suggesting that electronic, rather than steric, effects influence this angle. The fluoro complex 1 has the largest X-Ti-X and the smallest Cp-Ti-Cp angle. As expected, the average titanium-halogen distances follow the sequence $\mathrm{Ti}-\mathrm{F}<\mathrm{Ti}-\mathrm{Cl}<\mathrm{Ti}-\mathrm{Br}<\mathrm{Ti}-\mathrm{I}$.

\section{Conclusions}

The important message of this work is that we have structurally characterized the last member, namely the fluoro complex, of the $\left[\mathrm{Ti}\left(\eta^{5}-\mathrm{C}_{5} \mathrm{H}_{5}\right)_{2} \mathrm{X}_{2}\right](\mathrm{X}=$ halogenide $)$ family of complexes. Although the preparation of 1 was reported $\sim 55$ years ago, its exact molecular and crystal structure remained unknown until our report in this work. Studies are now underway in our laboratories to investigate the reactivity pattern of 1 with bidentate and tridentate $\mathrm{N}$ - or/and O-based ligands, and to study the hydrolytic behavior and cytotoxic activities of the resulting products. It should be mentioned that the fluoride ions themselves, if present in the products, are not cytotoxic at concentrations below $10^{-3} \mathrm{M}$ [16].

\section{Acknowledgment}

This paper is dedicated to Professor Dr. Nick Hadjiliadis for his contribution to the advancement of Bioinorganic Chemistry.

\section{References}

[1] S. J. Lippard and J. M. Berg, Principles of Bioinorganic Chemistry, University Science Books, Mill Valley, Calif, USA, 1994.

[2] P. Köpf-Maier, "Tumor inhibition by metallocenes: ultrastructural localization of titanium and vanadium in treated tumor cells by electron energy loss spectroscopy," Naturwissenschaften, vol. 67, pp. 415-426, 1980.

[3] P. Köpf-Maier, "Antitumor activity of titanocene dichloride in xenografted human renal-cell carcinoma," Anticancer Research, vol. 19, no. 1 A, pp. 493-504, 1999.

[4] M. M. Harding and G. Modski, "Antitumor metallocenes: structure-activity studies and interactions with biomolecules," Current Medical Chemistry, vol. 7, pp. 1289-1303, 2000.

[5] G. Mokdsi and M. M. Harding, "Inhibition of human topoisomerase II by the antitumor metallocenes," Journal of Inorganic Biochemistry, vol. 83, no. 2-3, pp. 205-209, 2001.

[6] C. V. Christodoulou, D. R. Ferry, D. W. Fyfe et al., "Phase I trial of weekly scheduling and pharmacokinetics of titanocene dichloride in patients with advanced cancer," Journal of Clinical Oncology, vol. 16, no. 8, pp. 2761-2769, 1998.
[7] K. Mross, P. Robben-Bathe, L. Edler et al., "Phase I clinical trial of a day-1, $-3,-5$ every 3 weeks schedule with titanocene dichloride (MKT 5) in patients with advanced cancer: a study of the phase I study group of the association for medical oncology (AIO) of the German Cancer Society," Onkologie, vol. 23, no. 6, pp. 576-579, 2000.

[8] A. Korfel, M. E. Scheulen, H.-J. Schmoll et al., "Phase I clinical and pharmacokinetic study of titanocene dichloride in adults with advanced solid tumors," Clinical Cancer Research, vol. 4, no. 11, pp. 2701-2708, 1998.

[9] B. Desoize, "Metals and metal compounds in cancer treatment," Anticancer Research, vol. 24, no. 3 A, pp. 1529-1544, 2004.

[10] F. Caruso and M. Rossi, "Antitumor titanium compounds," Mini-Reviews in Medicinal Chemistry, vol. 4, no. 1, pp. 49-60, 2004.

[11] E. Meléndez, "Titanium complexes in cancer treatment," Critical Reviews in Oncology/Hematology, vol. 42, no. 3, pp. 309-315, 2002.

[12] G. Lümmen, H. Sperling, H. Luboldt, T. Otto, and H. Rübben, "Phase II trial of titanocene dichloride in advanced renal-cell carcinoma," Cancer Chemotherapy and Pharmacology, vol. 42, no. 5, pp. 415-417, 1998.

[13] N. Kröger, U. R. Kleeberg, K. Mross, L. Edler, G. Saß, and D. K. Hossfeld, "Phase II clinical trial of titanocene dichloride in patients with metastatic breast cancer," Onkologie, vol. 23, no. 1, pp. 60-62, 2000.

[14] E. Y. Tshuva and D. Peri, "Modern cytotoxic titanium(IV) complexes; insights on the enigmatic involvement of hydrolysis," Coordination Chemistry Reviews, vol. 253, no. 15-16, pp. 2098-2115, 2009.

[15] K. Strohfeldt and M. Tacke, "Bioorganometallic fulvenederived titanocene anti-cancer drugs," Chemical Society Reviews, vol. 37, no. 6, pp. 1174-1187, 2008.

[16] S. Eger, T. A. Immel, J. Claffey et al., "Titanocene difluorides with improved cytotoxic activity," Inorganic Chemistry, vol. 49, no. 4, pp. 1292-1294, 2010.

[17] P. Köpf-Maier, B. Hesse, R. Voigtlaender, and H. Köpf, “Tumor inhibition by metallocenes: antitumor activity of titanocene dihalides $\left(\mathrm{C}_{5} \mathrm{H}_{5}\right)_{2} \mathrm{TiX}_{2}(\mathrm{X}=\mathrm{F}, \mathrm{Cl}, \mathrm{Br}, \mathrm{I}, \mathrm{NCS})$ and their application in buffered solutions as a method for suppressing druginduced side effects," Journal of Cancer Research and Clinical Oncology, vol. 97, no. 1, pp. 31-39, 1980.

[18] D. P. Fairlie, M. W. Whitehouse, and J. A. Broomhead, "Irritancy and anti-inflammatory activity of bis $\left(\eta^{5}\right.$ cyclopentadienyl)titanium(IV) complexes in rats," ChemicoBiological Interactions, vol. 61, no. 3, pp. 277-291, 1987.

[19] E. Dalas, N. Klouras, and C. Maniatis, "Inhibition of hydroxyapatite formation by titanocenes," Langmuir, vol. 8, no. 3, pp. 1003-1006, 1992.

[20] M. W. Carson and E. Lilly, "Difluorobis(cyclopentadienyl)titanium," in Encyclopedia of Reagents for Organic Synthesis, John Wiley \& Sons, 2003.

[21] G. Wilkinson and J. M. Birmingham, "Bis-cyclopentadienyl compounds of $\mathrm{Ti}, \mathrm{Zr}, \mathrm{V}, \mathrm{Nb}$ and $\mathrm{Ta}$," Journal of the American Chemical Society, vol. 76, no. 17, pp. 4281-4284, 1954.

[22] G. Brauer, Handbuch der Präparativen Anorganischen Chemie, vol. 1, F. Enke, Stuttgart, Germany, 6th edition, 1962.

[23] Rigaku/MSC, Crystal Clear, Rigaku/MSC, The Woodlands, Tex, USA, 2005.

[24] G. M. Sheldrick, SHELXS-97: Structure Solving Program, University of Göttingen, Göttingen, Germany, 1997.

[25] G. M. Sheldrick, SHELXL-97: Crystal Structure Refinement Program, University of Göttingen, Göttingen, Germany, 1997. 
[26] A. Clearfield, D. K. Warner, C. H. Saltarriaga-Molina, R. Ropal, and I. Bernal, "Structural studies of $\left(\pi-\mathrm{C}_{5} \mathrm{H}_{5}\right)_{2} \mathrm{MX}_{2}$ complexes and their derivatives. The structure of $\operatorname{bis}(\pi$ cyclopentadienyl)titanium dichloride," Canadian Journal of Chemistry, vol. 53, pp. 1622-1629, 1975.

[27] N. Klouras, V. Nastopoulos, I. Demakopoulos, and I. Leban, "Molecular and crystal structure of bis(cyclopentadienyl)titanium(IV) dibromide, $\mathrm{Ti}\left(\eta^{5}-\mathrm{C}_{5} \mathrm{H}_{5}\right)_{2} \mathrm{Br}_{2}$, " Zeitschrift für Anorganische und Allgemeine Chemie, vol. 619, pp. 19271930, 1993.

[28] L. I. Strunkina, M. Kh. Minacheva, K. A. Lyssenko et al., "Interaction of titanium(III) zwitterionic complex $\mathrm{Cp}\left[\eta^{5}-\mathrm{C}_{5} \mathrm{H}_{4} \mathrm{~B}\left(\mathrm{C}_{6} \mathrm{~F}_{5}\right)_{3}\right] \mathrm{Ti}$ with organic halides: synthesis and X-ray crystal structure determination of zwitterionic titanocene monohalides," Journal of Organometallic Chemistry, vol. 691, no. 4, pp. 557-565, 2006.

[29] H. Pink, Über reaktionen von biscyclopentadienyl-titan(IV)verbindungen $\left(\mathrm{C}_{5} \mathrm{H}_{5}\right)_{2} \mathrm{TiX}_{2}$ mit hydriden und doppelhydriden, Doctorate thesis, München, Germany, 1959.

[30] J. Bareš, P. Novák, M. Nádvorník et al., "Monomeric triorganotin(IV) fluorides containing a C,N-chelating ligand," Organometallics, vol. 23, no. 12, pp. 2967-2971, 2004.

[31] P. M. Druce, B. M. Kingston, M. F. Lappert, T. R. Spalding, and R. C. Srivastava, "Metallocene halides. Part I. Synthesis, spectra, and redistribution equilibria of $\mathrm{di}-\pi-$ cyclopentadienyldihalogeno-titanium(IV),-zirconium-(IV), and -hafnium(IV)," Journal of the Chemical Society A, pp. 2106-2110, 1969.

[32] K. Nakamoto, Infrared and Raman Spectra of Inorganic and Coordination Compounds, John Wiley \& Sons, New York, NY, USA, 4th edition, 1986.

[33] D. Hartley and M. J. Ware, "The vibrational spectra and assignment of bis-( $\pi$-cyclopentadienyl)- iron(II) and the bis( $\pi$-cyclopentadienyl)cobalt(III) cation," Journal of the Chemical Society A, pp. 138-142, 1969.

[34] K. K. Banger and A. K. Brisdon, "The first early transition metal perfluorovinyl complexes: the synthesis of $\mathrm{Cp}_{2} \mathrm{M}\left(\mathrm{CF}=\mathrm{CF}_{2}\right)_{n} \mathrm{X}_{2-n}\left(\mathrm{Cp}=\eta^{5}-\mathrm{C}_{5} \mathrm{H}_{5}^{-} ; \mathrm{M}=\mathrm{Ti}, \mathrm{Zr} ; \mathrm{X}=\right.$ $\mathrm{Cl}$ or $\mathrm{F})$ and structures of $\mathrm{Cp}_{2} \mathrm{Ti}\left(\mathrm{CF}=\mathrm{CF}_{2}\right)_{n} \mathrm{X}_{2-n}(\mathrm{X}=\mathrm{Cl}, \mathrm{F})$ via Ti K-edge EXAFS studies," Journal of Organometallic Chemistry, vol. 582, no. 2, pp. 301-309, 1999.

[35] C. H. Winter, X.-X. Zhou, and M. J. Heeg, "Approaches to hexane-soluble cationic organometallic Lewis acids. Synthesis, structure, and reactivity of titanocene derivatives containing polysilylated cyclopentadienyl ligands," Inorganic Chemistry, vol. 31, no. 10, pp. 1808-1815, 1992.

[36] A. J. Edwards, N. J. Burke, C. M. Dobson, K. Prout, and S. J. Heyes, "Solid state NMR and X-ray diffraction studies of structure and molecular motion in ansa-titanocenes," Journal of the American Chemical Society, vol. 117, no. 16, pp. 46374653, 1995. 


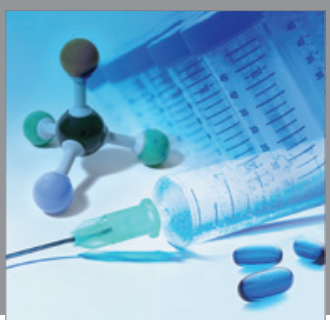

International Journal of

Medicinal Chemistry

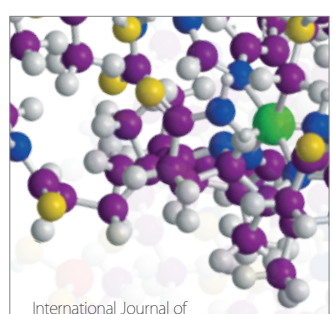

Carbohydrate Chemistry

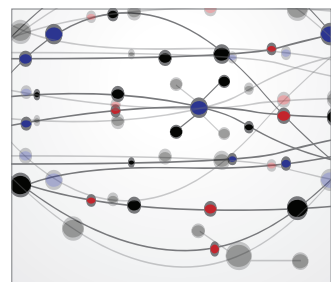

The Scientific World Journal
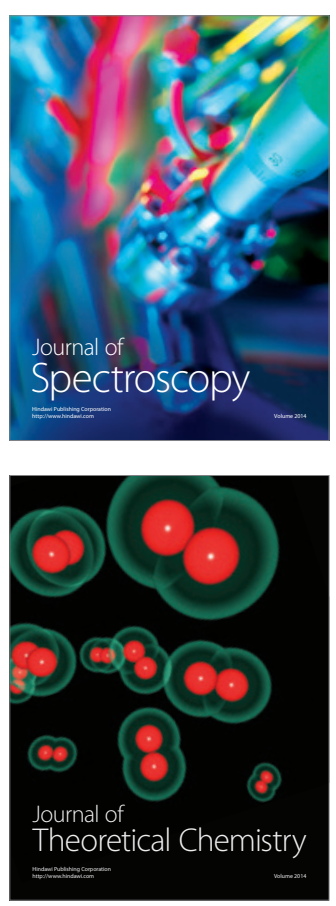
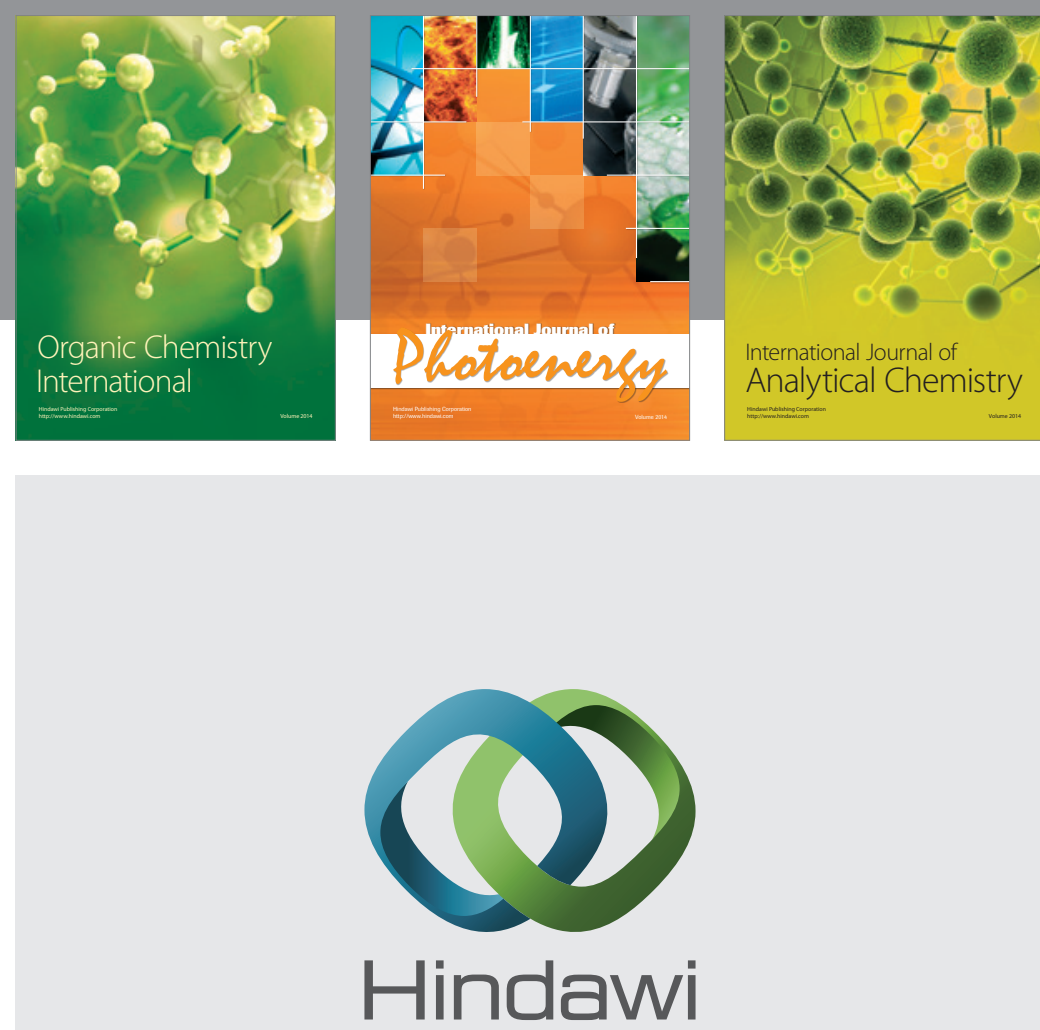

Submit your manuscripts at

http://www.hindawi.com
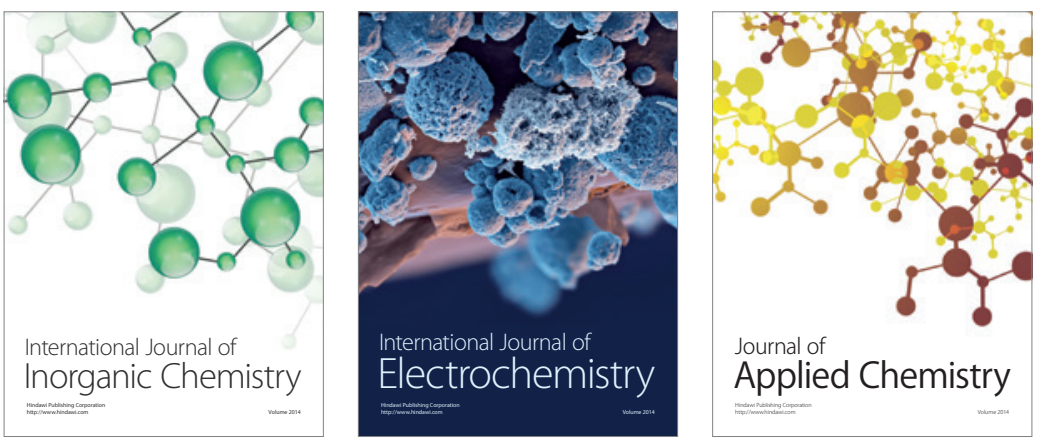

Journal of

Applied Chemistry
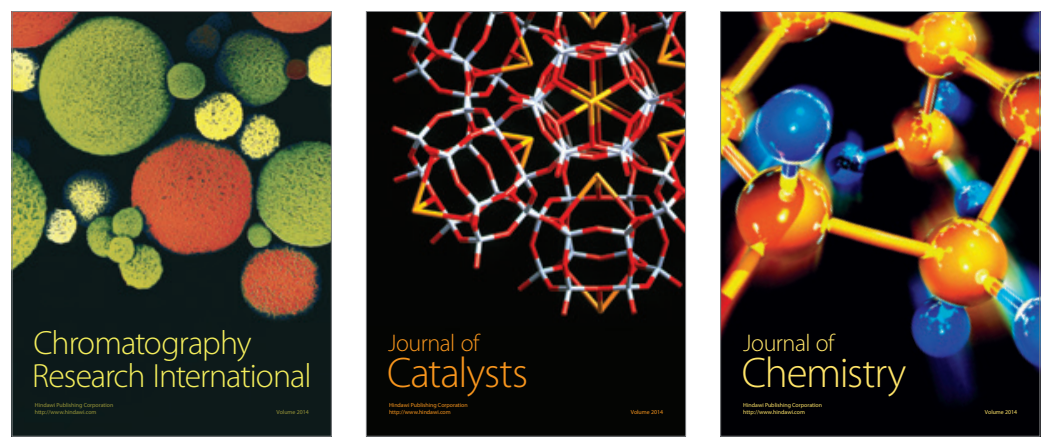
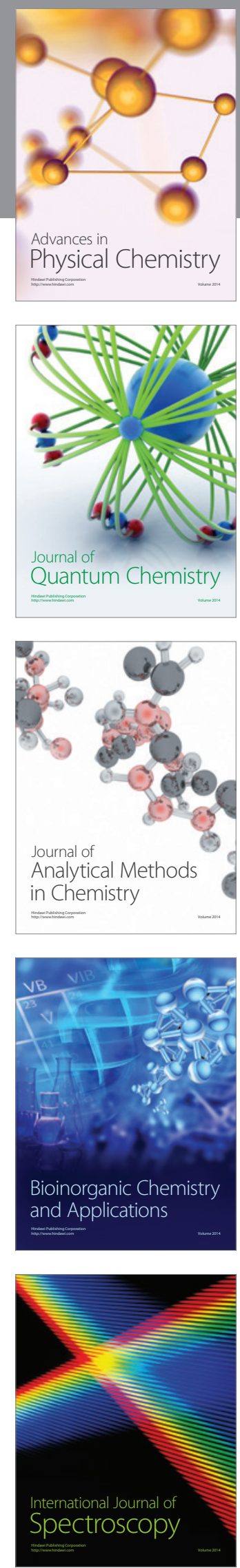